\title{
Performance and emission characteristics of biodiesel-blend in diesel engine: $A$ review
}

\author{
Yogesh PALANI $^{1}$, Chandramohan DEVARAJAN ${ }^{1}$, Dhanashekar MANICKAM ${ }^{{ }^{\dagger}}$, Sathish THANIKODI $^{2}$ \\ ${ }^{1}$ St. Peter's Institute of Higher Education and Research, Avadi, Chennai 600054, Tamil Nadu, India \\ ${ }^{2}$ Saveetha School of Engineering, SIMATS, Chennai 602105, Tamil Nadu, India
}

\begin{abstract}
Many researchers delve for an alternative fuel to overcome the fossil fuel crisis. Developed countries have embarked focus on renewable energy like wind energy, geothermal, biofuel, ocean energy and solar energy. Biodiesel is considered to be one of the most felicitous one kinds of renewable energy with similar properties of diesel fuel. Biodiesel is gaining prominence due to the global fossil fuel crisis and emission control challenges. Biodiesel blends are formulated in numerous proportion with diesel to run the diesel engine and it has significantly reduced the harmful pollutants from contaminating the environment. This review paper summarizes the outcome of biodiesel blends on properties, performance and emission-quality of a diesel engine under different operating conditions. Results from the literature provide a comparative data between conventional diesel and diesel-biodiesel blend which indicates that the diesel-biodiesel blend provides shorter ignition delay and lesser heat release rate as well as slightly higher efficiency. The emissions like CO, HC and particulate matter are reduced while choosing biodiesel blends. Biodiesel blend with additives such as alcohol can be the appropriate solution for the fuel crisis. Finally, the review concludes the advantages and future scope of biodiesel as a better competent for diesel fuel.
\end{abstract}

Keywords: Biodiesel, Biodiesel blend, Conventional diesel, Diesel engine, Emission gases

\section{Introduction}

The economy of any country is advanced by the operationalization of a better transportation system as the average consumption of energy by the transport sector increases $1.1 \%$ per year. The industrialization has led to an increase in energy consumption and demand. In the early stages to meet the energy demand crude oil was used as an alternative, and the world faced a shortage of crude oil from 1970. To resolve this issue, researchers and scientists around the world effectuated the research on developing alternative fuels. The population growth has led to the increased usage of automobiles resulting in the increase of harmful emission gases to the earth's atmosphere. Biodiesel combustion curtails the emission gases such as carbon monoxide, sulphur dioxide, unburned hydrocarbon, and nitrogen oxides, compared to conventional diesel fuel [1]. Many researchers [2-6] have reported that biodiesel and traditional diesel have indistinguishable physical and chemical properties. Ogunkunle et al. [7] have summarized the current global production and adoption of biodiesel as a vehicle engine fuel.
The use of biodiesel had an increasing trend because of its compatibility with a diesel engine without any modifications. Datta et al. [8] have presented a comprehensive review of biodiesel as an alternative fuel for compression ignition engine and conclude that the environmental aspects improved by using biodiesel but the engine performance deteriorates significantly.

Biodiesel produced from vegetable oil and animal fat is non-toxic. Advantages of biodiesel are high in cetane number and no sulphur. The major disadvantage is a hindrance in the complete replacement of conventional diesel fuel. Kinematic viscosity and density values are high for biodiesel with low calorific value and researchers [9-18] have experimented by blending biodiesel with diesel at various proportions to overcome the burning problem at low temperature and improve the engine performance. The optimum blend ratio B20 (20\% of biodiesel and $80 \%$ of diesel blend) improve density, viscosity, calorific value, flash point and better engine performance [9-11]. Lawan et al. [19] have reviewed the effects of bio-based additives on biodiesel properties. The efficacy of the bio-based additives depends on the content and type of phenolic
This is an Open Access article distributed under the terms of the Creative Commons Attribution Non-Commercial License (http://creativecommons.org/licenses/by-nc/3.0/) which permits unrestricted non-commercial use, distribution, and reproduction in any medium, provided the original work is properly cited.

Copyright (C) 2022 Korean Society of Environmental Engineers
Received June 15, 2020 Accepted December 23, 2020

${ }^{\dagger}$ Corresponding author

E-mail: dhanashekar.phd@gmail.com

Tel: +9677167683

ORCID: 0000-0001-8668-8894 
compounds present in the feedstock used for the antioxidation effects and freezing point level of the feedstock used for the cold flow depressing effect. Arjanggi et al. [20] have reviewed the advantages in the utilization of waste plastics as biodiesel additives and discussed the relevant knowledge on polymer dissolution phenomena, the effect of fuel properties, and the overall composition of biodiesel. Mohd Noor et al. [21] have performed a comprehensive review on biodiesel as an alternative fuel for marine diesel engine applications. Some obstacles that arise in marine applications are listed, such as fuel stability, higher production and feedstock costs, material compatibility, cold flow properties and lack of marine-grade standards which requires effective strategies and advanced technologies in future.

Gad et al. [22] have studied the effect of cotton ethyl ester blend enriched with HHO (2 hydrogen and 1 atom oxygen molecules) gas and kerosene additives on the performance and emissions characteristics of a diesel engine. The results show that the addition of kerosene additive enriched the cold flow properties. HHO inclusion enhanced combustion characteristics. Adu-Mensah et al. [23] have reviewed the developments associated with hydrogenated biodiesel to improve the oxidation stability without compromising the cold flow properties. They report a mixture of catalyst can be used to reduce the trans-FAME (fatty acid methyl esters) and partial hydrogenation. Chandran have reviewed the compatibility of biodiesel with fuel delivery materials (FDM) and the FDM degradation due to exposure to oxidized biodiesel containing oxidized products such as aldehydes, ketones and short-chain acids wasn't true for CRDE (common rail diesel engine) but the dissolved oxygen and conductivity value of biodiesel has an adverse effect [24].

Jiaqiang et al. [25] performed a comprehensive investigation on various technologies applied on the biodiesel fueled engines. They found the Low Temperature Combustion (LTC) mode is more efficient in reducing the $\mathrm{NO}_{\mathrm{x}}$ and $\mathrm{PM}$ emission when compared to other technologies like biodiesel additives, exhaust gas recirculation (EGR), water injection (WI), emulsion technology (ET), injection strategy modification, simultaneous technologies (ST), and combustion chamber geometry modification. Wang et al. [26] have reviewed the particulate matter (PM) emission characteristics of diesel engines with biodiesel or biodiesel blends and highlighted that the properties of biodiesel fuel such as the fatty acid chain length, the degree of unsaturation and oxygen content have the great effects on the PM emission.

Akhabue et al. [27], impregnated sulfonated calcined corncobs and calcined poultry droppings to prepare a novel bio-based bifunctional catalyst (BBFC). The neem seed oil (NSO) contains free fatty acid content of $4.426 \%$ treated with the bio-based catalyst. Ramalingam et al. [28] investigated the effects of moringa oleifera biodiesel blend using the advanced injection strategies on the diesel engine characteristics. They found the fuel injection pressure (300 bar to $600 \mathrm{bar})$ and timings $\left(15^{\circ} \mathrm{CA}\right.$ to $25^{\circ} \mathrm{CA}$ bTDC) have a significant effect on the engine emissions. The inclusion of moringa oleifera biodiesel blend has reduced the $\mathrm{CO}$ and $\mathrm{CO}_{2}$ emission to a greater extent when compared to $\mathrm{NO}_{\mathrm{x}}$ emissions. Suresh et al. [29] have reviewed the results of previous researchers using variable compression ratio (VCR) engine with direct injection of biodiesel blend fuel and suggested that VCR engine with optimum compression pressure enhances the engine performance and reduces the harmful emission gases.

Singh et al. [30] have reviewed the chemical compositions, properties, and standards for various biodiesels. They reported that the chemical and physical characteristics of biodiesel fuels are affected by the changes in the compositional element of FAME. Changes in chain branching, unsaturation and chain length would generate both desirable and undesirable changes in FAME properties. The compositional characteristics of FAME that enhance fuel stability could cause poor performance at low temperature. Composition of fatty acids reversely affects the characteristics of biodiesel, so it is difficult to find an accurate fatty acid composition. Cold flow, lubricity, viscosity, cetane number, and oxidative stability are the characteristics which illustrate the appropriateness of FAME as a biodiesel feedstock. Out of these characteristics, two are very important, i.e., oxidation stability and cold flow, because these two characteristics vary with the change in the feedstock. Good quality FAME should have less value of polyunsaturated fatty acid which leads to less oxidation instability.

Mirhashemi et al. [31] reviewed the potential of various biodiesel blends such as gasoline, hydrogen, natural gas, biogas, different types of alcohols to reduce $\mathrm{NO}_{\mathrm{x}}$ emissions. They have also reported that the proper injection parameters and blending proportions of fuels are to be set with the use of various fuel blends with biodiesel to reduce the $\mathrm{NO}_{\mathrm{x}}$ emissions. Erdiwansyah et al. [32] reported a comparative study on the effect of alcohol compared to gasoline and the effect of biodiesel compared to diesel for engine performance, combustion and emission characteristics. Highlighted the advantages and disadvantages of using alcohol and biodiesel in engines. Yesilyurt [33] investigated the performance, combustion, and exhaust emission characteristics of a diesel engine running on the blend of diesel fuel, biodiesel and 1-heptanol (C7 alcohol) as a next-generation higher alcohol. They observed that the addition of 1-heptanol as an oxygenated additive into the diesel fuel and biodiesel/diesel fuel blend caused a decreasing $\mathrm{CO}$ and unburned $\mathrm{HC}$ emissions while increasing $\mathrm{CO}_{2}, \mathrm{O}_{2}$, and $\mathrm{NO}_{\mathrm{X}}$ emissions as compared to diesel fuel.

Shahir et al. [34] reviewed the opportunities and prospects of using diesel-biodiesel-ethanol/bioethanol blend in the existing diesel engine. They reported that maintaining ethanol less than $5 \%$ has produced better results. Reducing the $\mathrm{NO}_{\mathrm{x}}$ emissions is still challenging, where additional catalytic convertors need to be attached to control it. Zaharin et al. [35] reviewed the effect of biodiesel blend with alcohol on diesel engine performance and emission gases. The addition of alcohol blend decreases the CO, HC, and $\mathrm{PM}$ emission while there is an increase in $\mathrm{NO}_{\mathrm{x}}$ emission. The more oxygen content enhances the complete combustion and increases the combustion temperature therefore the $\mathrm{NO}_{\mathrm{x}}$ emission increases. Mujtaba et al. [36] investigated the CI diesel engine characteristic of diesel-biodiesel blend with oxygenated alcohols and nanoparticle fuel additives. They noticed that the addition of alcohols $+\mathrm{B} 30$ reduce the $\mathrm{CO}$ and $\mathrm{HC}$ emissions while the addition of CNT nanoparticles $+\mathrm{B} 30$ reduces the $\mathrm{NO}_{\mathrm{x}}$ emission. Hasan et al. [37] reviewed the environmental and economic impacts of biodiesel production, the effect of biodiesel blends on engine durability, performance, and emission characteristics of IC engines. They conclude that a small content by volume of biodiesel blends 
can be supplied in the existing engines without any modifications. For a higher percentage of biodiesel and long term use, few engine modifications are mandatory.

Hosseinzadeh Bandbafha et al. [38] reviewed the life cycle assessment of biodiesel. Godri Pollitt et al. [39] have addressed the public health issues because of the increased usage of biodiesel fuel in IC engines. Researchers made some experimental studies using animal models to assess cardiovascular, respiratory, and systemic outcomes affected by biodiesel engine exhaust from soy- (B3-B100), rapeseed- (B20-30) corn- (B50, B100), and sewage- (B3-B100) derived biodiesel fuels. They reported that, in future, health policy should be framed, addressing the following topics: quality of biodiesel feedstock, standardized test protocols, assessment of gas pollutants induced.

Soudagar et al. [40] have listed the drawbacks of using biodiesel such as the increase in the nitrogen oxide emission, its incompatibility with cold weather conditions, and the regular intervals of engine parts replacement such as fuel filters, fuel tanks and fuel lines due to clogging. They have suggested that the addition of nanoparticles as fuel additives could improve the properties of biodiesel. Addition of metallic nanoparticles resulted in reduced ignition delay period, enhanced the calorific value and oxidation rates leading to a complete and cleaner combustion. Guo et al. [41] investigated the effects of using diesel, xylene, butanol, coconut oil and toluene on thermal oxidation and chemical structure in the diesel engine. These fuels individually experimented in an IC diesel engine. They concluded that thermal oxidation and chemical structure of fuels vary depending on the fuel identity. Biodiesel's soot is more reactive for more mass loss at a lower temperature range.

Several countries have embarked on the production and testing of biodiesel. Due to the higher cost of conventional diesel fuel, there is a higher demand for alternative fuel, and this biodiesel could be a better alternative. Biodiesel fuel has a broad sector of applications like heavy vehicles, marine engines and equipment machinery. The main objective of this review paper is to summarize the experimental studies made on diesel-biodiesel blends for improving the performance and reducing the harmful emission gases. From the literature, it can be noted that a detailed comparison provided on the performance characteristics of conventional diesel fuel and biodiesel blend fuel. At the same time, it can be found that only a few review papers are available on the outcome of additives in biodiesel. So, this review provides a brief discussion to substantiate the effect of adding additives like methanol, ethanol, butanol and propanol to dwindle emission gases.

\subsection{Characteristics of Biodiesel}

The engine efficiency depends on several parameters such as fuel properties, flash point, pour point, cetane number, density, kinematic viscosity, heating value, and calorific value. The physical and chemical characteristics of the biodiesel blends should meet the cut-off points framed by different standards like ASTM, EN, and ISO [42]. In recent years, mixing of at least two biofuels and diesel in addition to additive substances has become famous because it upgrades the fuel properties [43-46]. Biodiesel blend fuels may have distinct physical and compound properties, which influence engine performance and contamination in exhaust [43-45, 47].

\subsubsection{Calorific value}

Calorific value is identified as the most critical properties of any fuel since the power yield from the engine relies on it [45]. For instance, the calorific value of jatropha is $39.80 \mathrm{MJ} / \mathrm{kg}$, the palm is $40 \mathrm{MJ} / \mathrm{kg}$, and coconut oil is $38.50 \mathrm{MJ} / \mathrm{kg}$. The calorific value of biodiesel-diesel mixes is commonly higher than the biodiesel however lower than the conventional diesel fuel [46, 48]. For example, petroleum (46 MJ/kg), an oil (42 MJ/kg), yet higher than coal (32-36 MJ/kg) [49]. Reduction in the percentage of biofuel in biodiesel blend, the calorific value of biodiesel increases which results in the increased engine performance [50].

\subsubsection{Density}

The density of biodiesel fuel directly influences the engine power and outflow gases. The higher density causes higher viscosity that prompts legitimate ignition [27]. Usually, density will be identified with viscosity and cetane number. The biodiesel-diesel mixes have higher density compared to conventional diesel which results in increased size of fuel droplets. The density value impacts burning quality by changing the mass of fuel infusion [51, 52] and lower density value will expand the efficiency of atomization and air-fuel proportion development. The high density causes high discharge gases specifically $\mathrm{NO}_{\mathrm{x}}$ particulate matter [53-55]. From Figure 1, it is shown that the density of biodiesel varies based on the source and production method. Soybean biodiesel has a higher density $\left(931 \mathrm{~kg} / \mathrm{m}^{3}\right)$, while coconut biodiesel has a lower density (807.3 $\left.\mathrm{kg} / \mathrm{m}^{3}\right)$.

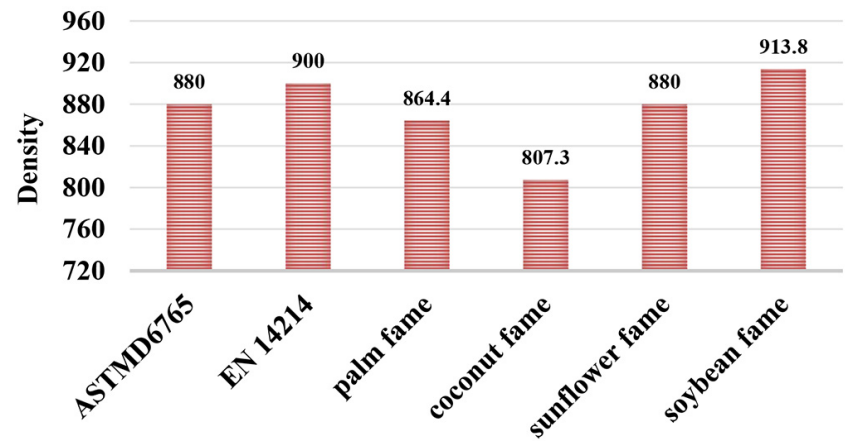

Fig. 1. Density values of bio-diesel fuel.

\subsubsection{Kinematic viscosity}

The viscosity of the fuel directly reflects the ignition of the IC engine [56]. The lower viscosity of fuel will elevate wear and leakage [57], and fuel with higher viscosity produces larger droplets at the moment of infusion and radiates a higher level of fumes gas emission. In cold weather conditions, the viscosity of the fuel increases and causes incomplete combustion [53, 58]. The viscosity of biodiesel fuel is higher compared to conventional diesel fuel and results in increased fuel consumption [59] as well as poorer spray and atomization [60, 61]. When biodiesel blends with diesel, it has a lower viscosity than diesel. The kinematic viscosity for sunflower oil biodiesel-diesel is 4.5-5.8 $\mathrm{mm}^{2} / \mathrm{s}$ and for palm oil biodiesel-diesel blend is $3.2-4.5 \mathrm{~mm}^{2} / \mathrm{s}$. Fig. 2 represents the kinematic viscosity values of various biodiesel fuel. 
8

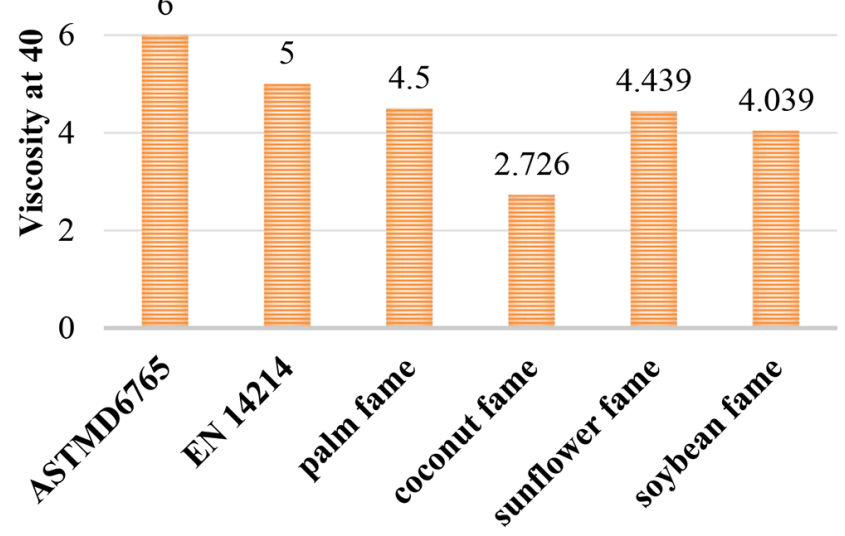

Fig. 2. Kinematic viscosity values of bio-diesel fuel.

\subsubsection{Cetane number}

The ignition quality of any fuel is determined based on its cetane number at a particular condition. The biodiesel fuel has a higher cetane number compared to diesel fuel. The cetane number should be higher to run the engine smoothly and noiseless, improve engine performance and reduce emission, [62]. The cetane number should be higher to shorten ignition delay [63, 64]. The lower cetane number will cause higher particulate matter and hydrocarbon emission. The increase in the biodiesel blend with diesel increases the cetane number as it decides ignition delay [65 - 67]. The cetane number of biodiesel ranges from 46.8-49.8, which is lower than the conventional diesel ranges from 46 to 55 . The cetane number of palm biodiesel is 54.6, sunflower biodiesel is 37.9 , peanut biodiesel is 53.59 and jatropha biodiesel is $51.6[68,69]$.

\subsubsection{Flash point}

The flash point is an important parameter which affects storage, transportation and handling of fuel. The fuel with higher flash points means it is safe during storage and transport [70]. The flash point of biodiesel will be $50 \%$ higher than the diesel, so it is safe for storage and shipment [71-77]. Flammability of fuel is the minimum temperature at which the fuel will have enough vapour to produce a flammable mixture above the fuel surface. According to the EU \& USA standard flash point of biodiesel is $92^{\circ} \mathrm{C}$ and $120^{\circ} \mathrm{C}$, respectively.

\subsubsection{Cloud and pour point}

Cloud and pour points are the fundamental parameters of fuel to assess the performance at low temperature, because of solidification the fuel may block or partially block the fuel lines, fuel filters will damage the engine due to insufficient lubrication. Biodiesel with a higher quantity of fatty acids maintains a high cloud and pour point compared to diesel. In cold weather conditions, the performance of diesel fuel is comparatively higher than biodiesel [78]. In cold weather conditions, the pour point and cloud point brings more complication in using biodiesel. The cloud point and pour point for palm oil biodiesel is 16 and 15, for soybean is 9 and 2 respectively [79].

\subsection{7. lodine value}

It is an essential parameter to evaluate the biodiesel suitability for long term engine use. The iodine value of a fuel is measured using $100 \mathrm{~g}$ of a sample of iodine added to the double bond of any fatty acid [80, 81]. Hevea brasiliensis has the highest iodine number of $144 \mathrm{mg} \mathrm{I} / \mathrm{g}$ and simarouba glauca (paradise tree) has the lowest iodine number of $40 \mathrm{mg} \mathrm{I} / \mathrm{g}$. There are two ASTM methods to measure iodine value D1959 and D1541 however this method is not suitable for stability tests such as cetane number, viscosity and cold flow characteristics because that depends on the position of the double bond which is available for oxidation [82]. The Soybean biodiesel has the highest iodine number range 128-143 and the lowest value for coconut biodiesel of about 19 .

\subsubsection{Copper content}

The copper contamination plays a significant role in use and storage to prevent the inappropriate change in the biodiesel properties [83-86]. The copper content present in ethanol, various biodiesel and water bonds is determined using Stripping chromo potentiometer (SCP). It is used to determine metal in the fuel, especially

Table 1. Properties of Biodiesel

\begin{tabular}{|c|c|c|c|c|c|c|}
\hline & ASTMD6765 & EN 14214 & $\begin{array}{c}\text { palm } \\
\text { FAME }\end{array}$ & $\begin{array}{c}\text { coconut } \\
\text { FAME }\end{array}$ & $\begin{array}{c}\text { sunflower } \\
\text { FAME }\end{array}$ & $\begin{array}{c}\text { soybean } \\
\text { FAME }\end{array}$ \\
\hline Cloud Point & -3 to- 12 & - & 16 & 0 & 3.4 & 9 \\
\hline Iodine Number & - & $\max .120$ & 54 & - & - & 142 \\
\hline Cetane Number & $\min .47$ & $\min .51$ & 54.6 & - & 49 & 37.9 \\
\hline Calorific Value & - & 35 & - & - & - & 39.76 \\
\hline Acid Value & $\max 0.50$ & $\max 0.5$ & 0.24 & 0.106 & 0.027 & 0.266 \\
\hline Pour Point & -15 & - & 15 & - & - & 2 \\
\hline Flash Point & $\min .100-170$ & 20 & 135 & 114.8 & 160 & 76 \\
\hline Cold Filter Plugging Point & 19 & $\max .+5$ & 12 & -4 & -3 & 11 \\
\hline Copper Strip Corrosion (3h at 50 ) & $\max .3$ & $\min .1$ & 1a & $1 \mathrm{~b}$ & 1a & $1 \mathrm{~b}$ \\
\hline Sulfur\% & $\max .0 .05$ & 10 & 0.003 & 3.2 & 0.2 & 0.8 \\
\hline Sulphated Ash\% & $\max .0 .02$ & $\max .0 .02$ & 0.002 & 0.006 & 0.005 & 0.005 \\
\hline
\end{tabular}


the oils to detect the metals and also help remove the remaining organic matter that will cause restriction problems in the system [87]. The metal availability and portable potent ability are determined using Stripping voltammeter.

\section{Performance Characteristics of Biodiesel in IC Engine}

Engine performance is another vital parameter which widely includes brake thermal efficiency, brake power, brake specific fuel consumption. In this section, a detailed discussion presented on the performance characteristics in terms of power, BSFC and BTE of a diesel engine using biodiesel-diesel blends.

\subsection{Brake Thermal Efficiency}

The BTE for biodiesel-diesel blend decreases slightly or remains the same compared to diesel fuel according to a few researchers [56, 79, 86]. Raman et al. [88] reported that B25 blend used in the diesel without modification of engine with acceptable thermal efficiency. Murillo et al. [4] found that the viscosity of biodiesel being higher is responsible for lower brake thermal efficiency. John panner selvam et al. [89] investigated and reported that the pure biodiesel obtained from beef tallow (B100) reduces thermal efficiency compared to diesel fuel with its blend (B5 to B78) because of the lower heating value of beef tallow biodiesel. Rajaraman et al. [90] studied the performance characteristics of moringa oil methyl ester and its blend (B20_B000) in diesel engine at various load conditions. They observed that compared to diesel fuel, moringa blends have lower brake thermal efficiency because of higher viscosity, lower heating value and density. Bari et al. [91] observed that the brake thermal efficiency was lower in the case of palm oil diesel than that of petro-diesel. The 10\% higher fuel consumption by palm oil diesel due to lower calorific value have reduced efficiency by $5 \%$. The combustion with palm oil diesel was better than the diesel due to the presence of fuel borne oxygen in palm oil diesel. Vijayakumar et al. [92] revealed that the alcohol fuel blend with biodiesel blends is very promising biodiesel for improving the performance of diesel engine operation. They confirmed that $25 \%$ of biodiesel of alcohol and diesel produced maximum efficiency. With an optimum proportion selected for adding the suitable alcohol additive to the biodiesel would improve the efficiency.

\subsection{Brake Specific Fuel Consumption}

Brake specific fuel consumption increases with an increase in the percentage of biodiesel in the biodiesel-diesel blends when used in CI engines [59, 66, 87, 93, 94]. The BSFC value decreases with increasing the engine load for all biodiesel fuels. Pramanik [95] investigated the performance of jatropha biodiesel with diesel blends. They found improved performance, a decline in the BSFC when compared to vegetable oil and the reason is dwindling in viscosity of jatropha. Asokan et al. [96] investigated and reported that the performance of B20 is almost in line with diesel fuel. For blends B20 and B30 at full load, the brake specific fuel consumption was close to conventional diesel fuel. Arumugam et al. [93] investigated a diesel engine by using fuel with $100 \%$ palm biodiesel without any engine modification. They declared that the brake power and torque are 10 to $12 \%$ less when the engine runs at full load condition with $100 \%$ palm biodiesel similar to diesel fuel. The brake specific fuel consumption was increased by 4 to $5 \%$. Srithar et al. [97] reported that BSFC reduces for all the dual biodiesel blends though brake power increases. The BSFC is an ideal variable because it is dependent on the calorific value of the fuel. The high energy consumption is due to the lower energy content of the ester. Bari et al. [91] concluded that BSFC was marginally higher for palm oil diesel due to lower calorific value and $10 \%$ higher than petro-diesel fuel. Jafari et al. [98] has investigated using six different fuels where diesel and coconut biodiesel used as base fuels and triacetin utilized as the oxygenated additive to biodiesel. They have developed a correlation matrix of various parameters. A few of them are speed, brake power, injection pressure, brake thermal efficiency, air-fuel equivalence ratio, start of injection, start of combustion, ignition delay, brake specific fuel consumption, density, oxygen content, more about exhaust emissions and particle morphology. They also found that fuel consumption increases with the increase in fuel oxygen content and the lower heating value (LHV) of the biodiesel and triacetin are less than diesel which leads to higher BSFC.

\subsection{Power}

A Greater or smaller reduction in engine power when using biodiesel-diesel blends with biodiesel of different origins are reported in many research. Murillo et al. [4] investigated the engine performance with a biodiesel blend in different percentages $(10 \%, 30 \%$, $50 \%$ ) in a four-stroke single-cylinder direct injection diesel engine under the various condition and then concluded increase in the biodiesel blend decreases the power output. Allen Jeffrey [99] found that effective power increases steady and then decreases with increase in load at fixed biodiesel percentage and compression ratio. The efficiency increases, when effective power decreases to a certain value and begins to increase with an increase in biodiesel percentage at stable equivalence ratio and compression ratio. Usta et al. [100] stated that higher power obtained for hazelnut soap stock, waste sunflower oil mixture and blends used in four-cylinder, indirect ignition diesel engines. The mixture of biodiesel to diesel fuel decreases its heating value. The existence of higher oxygen blends $(10 \%)$, the higher viscosity blends, a larger mass flow rate for the blends have a less internal leak in the fuel pump. They found that power decreases while the increase in the percentage of biodiesel is enriched.

\section{Emission Characteristics of Biodiesel in IC Engine}

Emission in $\mathrm{CI}$ engines consists of $\mathrm{NO}_{\mathrm{x}}$, Hydrocarbon (HC), carbon monoxide (CO) and particulate matter. The emission level varies according to engine parameters, fuel quality operating condition of the engine and engine design. The use of diesel- biodiesel blends which leads to a decrease in $\mathrm{CO}, \mathrm{NO}_{\mathrm{x}}, \mathrm{HC}$ and particulate matter compared to diesel fuel. The comparative result of each investigation related to the emission characteristics of biodiesel- diesel fuel blends with diesel fuel alone in different engines is documented in Table 2. 


\subsection{HC Emission}

The HC emission decrease when the diesel-biodiesel blend is used as fuel instead of diesel [101-103]. Motamedifar et al. [104] they found that minimum HC emission belongs to fuel blend D70B25E5 with the vane angles of $15^{\circ}$ and air swirl air D80B10E10. Celebi et al. [103] found that HC emission is slightly lesser than diesel fuel due to rich oxygen content of safflower biodiesel and butanol. Besides, a higher cetane number of biodiesel and better mixing properties of butanol shorten the ignition delay period and flame propagation which result in better combustion. Goga et al. [102] fuel blend B10 HC emissions were found to be lower than baseline diesel whereas the minimum amount of $\mathrm{HC}$ emissions were recognized for B20 which may be correlated with short ignition delay due to higher cetane number of biodiesel as compared to diesel. Shorter ignition delay period brings about more complete combustion of fuel and consequently, lower hydrocarbon exhalations are emitted. Addition of n-butanol in fuel blends attributed to increased $\mathrm{HC}$ emissions which may be due to longer ignition delay owing to low cetane number of higher alcohols. Partial combustion of fuel is achieved as a consequence of longer ignition delay period. The minimum value of $\mathrm{HC}$ exhalations was noted for B20 fuel blend at $20 \%$ engine load and maximum $\mathrm{HC}$, emissions were recorded for B20 nb20 fuel blend at 100\% load. For pure diesel the highest value of $\mathrm{HC}$ emissions were found to be $5.31 \mathrm{~g} / \mathrm{kWh}$ at $20 \%$ load and the lowest value of $5.01 \mathrm{~g} / \mathrm{kWh}$ was observed at full load conditions.

\subsection{CO Emission}

The CO emission decreases while using biodiesel-diesel blend compared to diesel fuel. Zheng et al. [105] investigated under reactivity controlled compression ignition (RCCI) mode, using n-butanol introduced to the cylinder by port injection. As the highly premixed charge distributed uniformly in the cylinder including the crevice region and boundary layer region near the cylinder liner, in which the fuel is hard to be oxidized completely, results in high CO emissions. Alptekin et al. [106] noticed the biodiesel emission had increased $\mathrm{CO}_{2}$ and $\mathrm{NO}_{\mathrm{x}}$ moreover they emit low carbon monoxide as compared to diesel fuel. They observed that the total HC emission increased while CO emission reduces slightly for blend contain bioethanol compared with B20 (20\% biodiesel, 80\% diesel fuel). Raman et al. [88] found that the CO emission is higher at lower loads when compared with engine operation at maximum load. The main reason for this is the existence of fuel rich mixture at higher loads. The CO emission of biodiesel blends is lower than the diesel engine. De Oliveira et al. [107] reported that the use of ethanol decreases the CO emission by $8.6 \%$ lower than B7. Using B7E5 CO emissions increased proportionally until the engine load reached $30 \mathrm{~kW}$. Beyond $30 \mathrm{~kW}$ load, CO emissions decrease, with a maximum reduction of $17.3 \%$ at $37.5 \mathrm{~kW}$ load. For B7E10 there was an increase in CO emissions between 10 and $20 \mathrm{~kW}$ load, reaching $21.3 \%$ at $10 \mathrm{~kW}$ load. For the engine loads of range 22.5 - $37.5 \mathrm{~kW}$ CO emissions reduced with increasing engine load, reaching a reduction of $22.7 \%$. B7E15 fuel showed an increase in specific emissions of $\mathrm{CO}$ in all load ranges, except for the load of $35 \mathrm{~kW}$, decreasing 9.8\%. For this fuel, the highest increase in CO emission occurred at $5 \mathrm{~kW}$, of $38.7 \%$.

\section{3. $\mathrm{NO}_{\mathrm{x}}$ Emission}

Most of the researchers agreed that the $\mathrm{NO}_{\mathrm{x}}$ emission of the biodiesel-diesel blend is higher than that of diesel fuel. Balamurugan et al. [87] declared the emission result and concluded that $\mathrm{NO}_{\mathrm{x}}$ emission was decreased by $6.098 \%, 19.668 \%, 11.585 \%$ and $14.389 \%$ for the incorporation of $4 \%$ propanol, $8 \%$ propanol, $4 \%$ butanol \& $8 \%$ butanol with diesel, respectively. The density of exhaust smoke raised by $12.891 \%, 5.077 \%, 11.339 \%$ and $14.063 \%$ for addition of $4 \%$ propanol, $8 \%$ propanol, $4 \%$ butanol and $8 \%$ butanol with diesel, respectively. Motamedifar et al. [104] reported that the NO emission will be maximum for D100 vane angle of $45^{\circ}$ and swirl air. The higher temperature and premixed combustion with higher vane angles of $45^{\circ}$ will cause an increase in $\mathrm{NO}_{\mathrm{x}}$ emission. This emission occurs at D70B25E5 because of higher biodiesel content as an oxygenated fuel.

Leite et al. [108] found that $\mathrm{NO}_{\mathrm{x}}$ emission increases for an increase in crambe oil in the proportion. Ashokan et al. [96] found that NOx emission increases at lower loads due to the increase in combustion temperature. $\mathrm{NO}_{\mathrm{x}}$ emission of B100 is higher compared with diesel at full load while other blends are nearer to diesel fuel. Kandasamy et al. [109] found that $\mathrm{NO}_{\mathrm{x}}$ emission decreased for B5E20 compared to B5 for lower to medium speed range however, it increased further at higher speeds. Moreover, at $0 \mathrm{~h}$ and full load performance, the $\mathrm{NO}_{\mathrm{x}}$ formation for B5E20 fuelled engine is the least between lower and medium speed range. With speed increases the $\mathrm{NO}_{\mathrm{x}}$ formation increases for all the fuels at low to medium speeds and attains the peak value, where the complete combustion takes place results in peak in-cylinder temperature. In this study, $\mathrm{NO}_{\mathrm{x}}$ formation and the maximum peak temperature occur near the maximum torque region where the combustion is complete. The highest $\mathrm{NO}_{\mathrm{x}}$ emissions among the tested conditions have been observed with B5E20 after 500 h durability cycle corresponding to the maximum torque speed. Formation of oxides of nitrogen in a diesel engine is because of many parameters such as air-fuel ratio, cetane number, the oxygen content of the fuel and combustion temperature. The increasing trend of $\mathrm{NO}_{\mathrm{x}}$ formation for B5E20 is due to increased ignition delay period by the addition of ethanol in the fuel composition. The introduction of ethanol to base fuel results in decreasing the cetane number of the ethanol blended biodiesel (B5E20) which leads to increased ignition delay period and results in accumulation of more fuel/air mixture at the combustion zone.

\subsection{Particulate Matter}

The use of diesel-biodiesel blends reduces particulate matter emissions compared to diesel fuel. Zare et al. [110] observed that the particulate matter emissions depend on various factors such as temperature, engine speed, fuel properties, engine load, and after-treatment systems. In the exhaust gas emissions, particulate matter, liquid and solid mixtures is a complicated pollutant which is not a chemically well-defined substance in terms of how it forms, what it is composed of and how it can be controlled. During a cold start, adding $5 \%$ waste lubricating oil to the blend decreased PN by $43 \%$, while during steady-state it increased PN by $13 \%$. Vijayakumar et al. [92] have found that maximum smoke particulate matter observed for D55 at 20\%, 40\% and 60\% loads. The D65 
Table 2. Performance and Emission Result for Various Test Condition

\begin{tabular}{|c|c|c|c|c|c|c|c|c|c|}
\hline \multirow{2}{*}{ Engine } & \multirow{2}{*}{$\begin{array}{l}\text { Ref } \\
\text { No. }\end{array}$} & \multirow{2}{*}{ Fuel } & \multirow{2}{*}{$\begin{array}{l}\text { Experiment } \\
\text { Condition }\end{array}$} & \multicolumn{6}{|c|}{ Compared to Diesel fuel } \\
\hline & & & & Efficiency & BSFC & CO & HC & NO & Smoke \\
\hline \multirow{6}{*}{$\begin{array}{l}\text { Single cylinder diesel } \\
\text { engine }\end{array}$} & {$[97]$} & $\begin{array}{l}\text { Pongamina } \\
\text { Pinnata oil \& } \\
\text { mustard oil }\end{array}$ & $\begin{array}{l}\text { Constant speed } \\
\text { (300 rpm) }\end{array}$ & $\begin{array}{c}0.9 \% \\
\text { increase }\end{array}$ & $\mathrm{H}$ & $\mathrm{L}$ & $\mathrm{H}$ & $\mathrm{H}$ & $\mathrm{H}$ \\
\hline & [102] & Rice bran oil & $\begin{array}{l}\text { Constant speed } \\
(1,550 \mathrm{rpm})\end{array}$ & $\begin{array}{c}2 \% \\
\text { increase }\end{array}$ & $\mathrm{H}$ & $\mathrm{L}$ & $\mathrm{L}$ & $\mathrm{L}$ & $\mathrm{L}$ \\
\hline & [114] & Rice bran oil & Different load & $S$ & $\mathrm{H}$ & $\mathrm{H}$ & $\mathrm{H}$ & - & - \\
\hline & [115] & Palm oil & $\begin{array}{l}\text { Variable compression ratio } \\
\qquad(16: 1,17: 1,18: 1)\end{array}$ & $\mathrm{L}$ & $\mathrm{L}$ & $\mathrm{L}$ & $\mathrm{L}$ & $\mathrm{H}$ & $\mathrm{L}$ \\
\hline & [88] & Rapo seed oil & $\begin{array}{l}\text { Constant speed }(1,500 \mathrm{rpm}) \text { and } \\
\text { constant injection of } 20 \mathrm{bar}\end{array}$ & $S$ & $\mathrm{H}$ & $\mathrm{L}$ & $\mathrm{L}$ & $\mathrm{H}$ & $\mathrm{L}$ \\
\hline & [91] & Palm oil & $\begin{array}{c}\text { Different speed }(2,000,2,500, \\
2,800) \mathrm{rpm}\end{array}$ & - & $\mathrm{H}$ & $\mathrm{L}$ & $\mathrm{L}$ & $\mathrm{H}$ & - \\
\hline $\begin{array}{l}\text { Single cylider direct } \\
\text { injection engline }\end{array}$ & {$[103]$} & Safflones oil & Constant speed 1,500 rpm & $\mathrm{H}$ & $\mathrm{S}$ & $S$ & - & $\mathrm{S}$ & - \\
\hline \multirow{4}{*}{ diesel engine } & [116] & $\begin{array}{l}\text { Pongamia oil } \\
\text { \&waste cooking } \\
\text { oil }\end{array}$ & $\begin{array}{l}\text { At different loads }(30 \%, 50 \% \text {, } \\
\qquad 20 \%, 100 \%)\end{array}$ & $\mathrm{S}$ & $\mathrm{H}$ & $\mathrm{L}$ & $\mathrm{L}$ & $\mathrm{H}$ & - \\
\hline & [117] & Cotton seed & $\begin{array}{l}\text { Different load }(20 \%, 40 \%, 60 \% \text {, } \\
\quad 80 \%, 100 \%)\end{array}$ & Increase & $\mathrm{L}$ & $S$ & $\mathrm{~L}$ & $\mathrm{~L}$ & $\mathrm{H}$ \\
\hline & [118] & Palm oil & $\begin{array}{l}\text { Different speed }(1,000,1,800 \\
2,000,2,500,3,000 \mathrm{rpm})\end{array}$ & - & $\mathrm{H}$ & $S$ & $\mathrm{~L}$ & $\mathrm{H}$ & - \\
\hline & [119] & $\begin{array}{l}\text { Jatropha meringa } \\
\text { palm }\end{array}$ & $\begin{array}{c}\text { Different speed (100 to 400) } \\
\text { rpm }\end{array}$ & - & $\mathrm{H}$ & $\mathrm{L}$ & $\mathrm{H}$ & $\mathrm{H}$ & - \\
\hline \multirow{2}{*}{$\begin{array}{l}\text { Direct injection diesel } \\
\text { engine }\end{array}$} & {$[96]$} & Juliflora oil & $\begin{array}{c}\text { Different load } \\
(30,50,70,100)\end{array}$ & $\mathrm{L}$ & $\mathrm{H}$ & $S$ & $\mathrm{~L}$ & $S$ & $\mathrm{H}$ \\
\hline & [120] & Palm oil & $\begin{array}{l}\text { Different speed }(1,700,1,800 \text {, } \\
1,900,2,100,2,300,2,500) \mathrm{rpm}\end{array}$ & $\mathrm{L}$ & $\mathrm{H}$ & $\mathrm{L}$ & $\mathrm{L}$ & $\mathrm{H}$ & - \\
\hline $\begin{array}{l}\text { Multi fuel direct } \\
\text { injection }\end{array}$ & [121] & Palm oil & $\begin{array}{l}\text { Direct injection pressure } \\
(190,140,230) \text { bar }\end{array}$ & - & $\mathrm{L}$ & $\mathrm{H}$ & - & $\mathrm{L}$ & - \\
\hline $\begin{array}{l}\text { Two cylinder } 4 \text { stroke } \\
\text { diesel engine }\end{array}$ & {$[94]$} & Palm oil & & $\mathrm{S}$ & $\mathrm{H}$ & $\mathrm{L}$ & $S$ & $\mathrm{~L}$ & - \\
\hline $\begin{array}{l}\text { Four cylinder diesel } \\
\text { engine }\end{array}$ & {$[122]$} & Waste cooking oil & Constant speed 1,600 rpm & $\mathrm{S}$ & $\mathrm{H}$ & $\mathrm{L}$ & - & $\mathrm{L}$ & - \\
\hline
\end{tabular}

Where; H- Higher, L- Lower, S-Similar

fuel blends produced maximum smoke particulate matter emissions at $80 \%$ and $100 \%$ loads. All the alcohol blends produced lower smoke particulate matter compared with base diesel fuel.

Verma et al. [111] studied with 5 blends i.e. mixed orange oil, tea tree oil, eucalyptus oil individually, a blend of commercially available biodiesel with diesel and petrol blended diesel. The oxygen content for these fuel blends is maintained between $0 \%$ and $2.2 \%$. For oxygen generated fuels, the primary particle diameter decreases and the fractal dimensions of soot aggregates increase. Diesel has complex aggregate geometry and almost spherical shape. Also, for oxygenated fuels, the fringes are shorter and more curved when compared to that of diesel and they have a more disordered configuration. A higher fringe length is observed for oxygenated fuel when compared to diesel. Verma et al. [112] they have considered butanol as the primary fuel, blended with diesel $(20 \%$ to $30 \%)$. They maintained the required oxygen content percentage between $0-4$ to $32 \%$ and $6.48 \%$ and observed that the fuel oxygen content increases the reactivity of soot particles, produce a more compact and smaller particle.

Verma et al. [113] reported that the fuels used to involve a series of blends of biodiesel at various concentrations (B20 B50 B96 B100) with triacetin. The oxygen content of the fuel ranges from $0 \%$ to $14 \%$. The particulate matter is analysed using a Transmission Electron Microscope (TEM) at low and high spatial resolutions. They observed that by increasing the oxygen content, there is a decrease in primary particle diameter and radius of gyration 
for various speeds and loads when compared to diesel. By increasing oxygen content, the fraction dimension increases when compared to diesel. The internal structure of soot particles appears to have a disordered arrangement of graphene layers for fuels having oxygen content up to $11.01 \%$, which is the oxygen level content for pure biodiesel. Table. 2 shows the performance and emission results from the various references.

\subsection{Combustion Characteristics}

Combustion characteristics are an important distinction of fuel on which engine performance and emission are strongly dependent. The combustion process is explained by a few parameters such as ignition delay, heat release, combustion duration, cumulative heat release, cylinder pressure. In this section, a review of combustion characteristics in terms of heat release rate, ignition delay period and the cylinder pressure. The biodiesel-diesel blends used in CI engines are presented with some brief discussion.

\subsection{Heat Release Rate}

The biodiesel-diesel blend from biodiesels of different origins provided a lower peak heat release than diesel fuel [45, 60, 66, 87]. Qi et al. [123] found that peak heat release rate of biodiesel is higher than the diesel fuel under low engine loads [20\% of full engine load], but the inverse is true under high engine loads [95\% of full engine load]. Abu-Jrai et al. [124] compared the heat release rate for biodiesel-diesel blend and diesel at 25\%, 50\% and 75\% of full engine load. The increase of load from low to medium the maximum heat release rate increases, however, the opposite phenomenon occurs under high load. The maximum heat release rate occurs at maximum engine load closer to the top dead centre. An increase in the maximum heat release rate and the fraction of fuel burned in the premixed combustion phase because of an increase in the oxygen fraction of the injected fuel at high engine speed. Lakshmi Narayana Rao et al. [125] investigated the heat release rate of jatropha methyl ester biodiesel biodiesel-diesel blend in their combustion characteristics analysis. They observed that the value of the maximum heat release rate decreased with an increase in the proportion of jatropha methyl ester biodiesel in the fuel. In diesel, fuel ignition delay was longer compared to biodiesel-diesel blend which allowed more fuel and air to mix properly. Ultimately, this resulted in a higher heat release rate for diesel.

\subsection{Ignition Delay}

Most of the researchers found that biodiesel-diesel blend provides a shorter ignition delay than diesel fuel. Lakshmi Narayana Rao et al. [125] found that the ignition delay decreased with increase in the amount of jatropha methyl ester biodiesel in the blend under all loads. This is because of the oxygen content of jatropha methyl ester biodiesel which improves the ignitability as well as splitting the heavier compounds of fatty acid present in jatropha methyl ester biodiesel into smaller compounds, which produces more volatile matter, which in return causes earlier ignition. Jafari et al. [98] reported that longer ignition delay and higher engine speeds can increase the nucleation of particular emission. If the oxygen content increases then the aggregate compactness of unburnt carbon increases. The fuel oxygen accumulation reduces the particle mass and number of soot particles.

\section{Conclusions}

The effects on engine performance, emission and characteristics were reviewed according to various operation conditions, different engine tests, reference diesel fuel tests and various measurement techniques. The overall conclusions that can be drawn are,

1) The ignition delay is reduced in the biodiesel-diesel blend fuels due to the increase in the oxygen supplied.

2) The biodiesel-diesel blend fuel with additives has lower calorific value, high flashpoint and increased density.

3) The additives increase the oxygen supply and combustion rate is high thereby increasing the fuel consumption.

4) Many researchers reported that CO, HC and particulate matter emissions are reduced with the inclusion of additives in the biodiesel-diesel blends. Sometimes a slight increase in biodiesel blend tends to increase in $\mathrm{NO}_{\mathrm{x}}$ emission.

5) The optimization of additives and biodiesel proportion can lead to minimum alterations of the diesel engine and enhances the oxidation stability. Utilizing bio based additives can improve the life of the engine parts and reduces the $\mathrm{NO}_{\mathrm{x}}$ emission to some extent.

\section{Author Contributions}

Y.P. (Research Scholar) wrote the manuscript, C.D. (Professor) wrote the manuscript, D.M. (Associate Professor) revised the manuscript, and S.T. (Associate Professor) revised the manuscript.

\section{References}

1. Sundaresan M, Chandrasekaran S, Tamil Porai P. Analysis of combustion, Performance and emission characteristics of blends of methyl esters of jatropha oil (MEJ) in DI diesel engine. $S A E$ Tech. Pap. 2007;32:1-6.

2. Canakei M. Combustion characteristics of a turbocharged DI compression ignition engine fuelled with petroleum diesel fuels and biodiesel. Bioresour. Technol. 2007;86:1765-1771.

3. Alptekin E, Canakei M. Determination of the density and the viscosities of biodiesel-diesel fuel blends. Renew. Energ. 2008;33:2623-2630.

4. Murillo S, Miguez JL, Porteiro J, Granada E, Moran JC. Performance and exhaust emissions in use of biodiesel in outboard diesel engines. Fuel 2007;86:1765-1771.

5. Nabi MN, Akhter MS, Zaglul Shahadat MM. Improvement of engine emissions with conventional diesel fuel and diesel-biodiesel blends. Bioresour. Technol. 2006;97:372-378.

6. Sharma D, Soni SI, Pathak SC, Gupta R. Performance and emission characteristics of direct injection diesel engine using neem-diesel blends. J. Inst. Eng. (India):Mech. Eng. Div. 2005;86: 77-83.

7. Ogunkunle O, Noor A. Ahmed. A review of global current scenar- 
io of biodiesel adoption and combustion in vehicular diesel engines. Energy Rep. 2019;5:1560-1579.

8. Datta A, Mandal BK. A comprehensive review of biodiesel as an alternative fuel for compression ignition engine. Renew. Sust. Energ. Rev. 2016;57:799-821.

9. Sharp CA, Ryan TW, Knothe G. Heavy-Duty diesel engine emissions tests using special biodiesel fuels. SAE Transactions. 2005;114:1204-1212.

10. Suryawanshi J, Deshpande N. Overview of EGR injection timing and pressure on emissions and performance of CI engine with pongamia methyl ester. SAE Tech. Pap. 2005;26:1-10.

11. Sirman MB, Owens EC, Whitney KA. Emissions comparison of alternative fuels in an advanced automotive diesel engine. SAE Transactions. 2000;109:2166-2176.

12. Krahl J, Munack A, Bahadir M, Schumacher L, Elser N. Review utilization of rapessed oil, rapeseed oil methyl ester or diesel engine fuel: exhaust gas emissions and estimation of environmental effects. SAE Tech. Pap. 1996;962096.

13. Rao PS, Gopalakrishnan KV. Vegetable oils and their methyl esters as fuels for diesel engines. Indian J. Technol. 1991;29: 292-297.

14. Rakopoulos CD, Hountalas DT, Rakopoulos DC, Glakoumis EG. Experimental release rate analysis in both chambers of an indirect injection turbocharged diesel engine at various load and speed conditions. SAE Transactions. 2005;114:867-882.

15. Agarwal AK, Das L. Biodiesel development and characteristics for use as a fuel in compression ignition engines. J. Eng. Gas Turbine Power. 2001;123:440-447.

16. Rosea R, Rakosi E, Manolache G, Nieulana M. Fuel and injection characteristics for a biodiesel type fuel from waste cooking oil. SAE Tech. Pap. 2005;2005-01-3674.

17. Kumar MS, Ramesh A, Nagalingam B. Experimental investigation on a Jatropha oil methanol dual fuel engine. SAE Tech. Pap. 2001;2001-01-0153.

18. Rao G, Prasad A, Mohan PR. Performance evaluation of DI and IDI engines with Jatropha oil based biodiesel. J. Inst. Eng. (India): Mech. Eng. Div. 2005;86:72-76.

19. Lawan I, Zhou W, Garba ZN, Zhang M, Yuan Z, Chen L. Critical insights into the effects of bio-based additives on biodiesels properties. Renew. Sust. Energ. Rev. 2019;102:83-95.

20. Arjanggi RD, Kansedo J. Recent advancement and prospective of waste plastics as biodiesel additives: A review. J. Energy Inst. 2020;93:934-952.

21. Mohd Noor CW, Noor MM, Mamat R. Biodiesel as alternative fuel for marine diesel engine applications: A review. Renew. Sust. Energ. Rev. 2018;94:127-142.

22. Gad MS, El-Fakharany MK, Elsharkawy EA. Effect of HHO gas enrichment on performance and emissions of a diesel engine fueled by biodiesel blend with kerosene additive. Fuel 2020;280: 118632.

23. Adu-Mensah D, Mei D, Zuo L, Zhang Q, Wang J. A review on partial hydrogenation of biodiesel and its influence on fuel properties. Fuel 2019;251:660-668.

24. Chandran D. Compatibility of diesel engine materials with biodiesel fuel. Renew. Energ. 2020;147:89-99.

25. Jiaqiang E, Pham M, Zhao D, et al. Effect of different technologies on combustion and emissions of the diesel engine fueled with biodiesel: A review. Renew. Sust. Energ. Rev. 2017;80:620-647. 26. Wang Y, Liu H, Lee C.-F. Particulate matter emission characteristics of diesel engines with biodiesel or biodiesel blending: A review. Renew. Sust. Energ. Rev. 2016;64:569-581.

27. Akhabue CE, Osa-Benedict EO, Oyedoh EA, Otoikhian SK, Development of a bio-based bifunctional catalyst for simultaneous esterification and transesterification of neem seed oil: Modeling and optimization studies, Renew. Energ. 2020;52: 724-735.

28. Ramalingam S, Mahalakshmi NV. Influence of high pressure fuel injection system on engine performance and combustion characteristics of Moringa Oleifera biodiesel and its blends. Fuel 2020;279:118461.

29. Suresh M, Jawahar CP, Richard A, A review on biodiesel production, combustion, performance, and emission characteristics of non-edible oils in variable compression ratio diesel engine using biodiesel and its blends. Renew. Sust. Energ. Rev. 2018;92:38-49.

30. Singh D, Sharma D, Soni SL, Sharma S, Kumari D. Chemical compositions, properties, and standards for different generation biodiesels: A review. Fuel 2019;253:60-71.

31. Mirhashemi FS, Sadrnia H. NOX emissions of compression ignition engines fueled with various biodiesel blends: A review. J. Energy Inst. 2020;93:129-151.

32. Erdiwansyah, Mamat R, Sani MSM, Sudhakar K, Asep Kadarohman, Sardjono RE. An overview of Higher alcohol and biodiesel as alternative fuels in engines. Energy Rep. 2019;5: 467-479.

33. Yesilyurt MK. A detailed investigation on the performance, combustion, and exhaust emission characteristics of a diesel engine running on the blend of diesel fuel, biodiesel and 1-heptanol (C7 alcohol) as a next-generation higher alcohol. Fuel 2020;275:117893.

34. Shahir SA, Masjuki HH, Kalam MA, Imran A, Ashraful AM. Performance and emission assessment of diesel-biodiesel-ethanol/ bioethanol blend as a fuel in diesel engines: A review. Renew. Sust. Energ. Rev. 2015;48:62-78.

35. Zaharin MSM, Abdullah NR, Najafi G, Sharudin H, Yusaf T. Effects of physicochemical properties of biodiesel fuel blends with alcohol on diesel engine performance and exhaust emissions: A review. Renew. Sust. Energ. Rev. 2017;79:475-493.

36. Mujtaba MA, Kalam MA, Masjuki HH, et al. Comparative study of nanoparticles and alcoholic fuel additives-biodiesel diesel blend for performance and emission improvements. Fuel 2020;279:118434.

37. Hasan MM, Rahman MM, Performance and emission characteristics of biodiesel-diesel blend and environmental and economic impacts of biodiesel production: A review. Renew. Sust. Energ. Rev. 2017;74:938-948.

38. Hosseinzadeh BH, Tabatabaei M, Aghbashlo M, Khanali M, Demirbas A. A comprehensive review on the environmental impacts of diesel/biodiesel additives, Energy Convers. Manage. 2018;174:579-614.

39. Godri Pollitt KJ, Chhan D, Rais K, Pan K, Wallace JS. Biodiesel fuels: A greener diesel? A review from a health perspective. Sci. Total Environ. 2019;688:1039-1055.

40. Soudagar MEM, Nik-Ghazali N-N, Abul Kalam M, Badruddin 
IA, Banapurmath NR, Akram N. The effect of nano-additives in diesel-biodiesel fuel blends: A comprehensive review on stability, engine performance and emission characteristics. Energy Convers. Manage. 2018;178:146-177.

41. Guo Y, Ristovski Z, Graham E. The correlation between diesel soot chemical structure and reactivity. Carbon 2020;161: 736-749.

42. Arbab MI, Masjuki HH, Varman M, Kalam MA, Imtenan S, Sajjad H. Fuel properties, engine performance and emission characteristics of common biodiesels as a renewable and sustainable source of fuels. Renew. Sust. Energ. Rev. 2013;22:133-147.

43. Teixeria LSG, Couto MB, Souza GS, Filho MA, Assis JCR, Guimaraes PRB. Characterization of beef tallow biodiesel and their mixtures with soybean biodiesel and mineral diesel fuel. Biomass Bioenergy. 2010;34:438-441.

44. Kwanchareon P, Luengnaruemitchai A, Jai-In S. Solubility of a diesel- biodiesel- ethanol blend, its fuel properties, and its emission characteristics from diesel engine. Fuel 2007;86: 1053-1061.

45. Sanjid A, Masjuki HH, Kalam MA, Production of palm and Jatropha based biodiesel and investigation of palm-jatropha combined blend properties, performance. Exhaust emission and noise in an unmodified diesel engine. J. Cleaner Prod. 2014;65:295-303.

46. Silitonga AS, Masjuki HH, Mahlia TMI. Overview properties of biodiesel diesel blends from edible and non-edible feedstock. Renew. Sust. Energ. Rev. 2013;22:346-360.

47. Dantas MB, Albuquerque AR, soledade LEB, Queiroz N, Maia ASI, Santos IMG. Biodiesel from soybean oil. Castor oil and their blends: Oxidative stability by PDSC and rancimat. J. Therm. Anal. Calorim. 2011;106:607-11.

48. Silitonga AS, Ong HC, Mahlia TMI. Characterization and production of ceiba pentandra biodiesel and its blends. Fuel 2013;108:855-858.

49. Oliveria LE, Da Silva MLCP. Comparative study of calorific value of rapessed, soyabean, Jatropha curcas and cranbe biodiesel. International conference on Renewable energies and power quality (ICREPQ). 2013;20-22.

50. Ashraful AM, Masjuki H, Kalam M. Production and comparison of fuel properties, engine performance, and emission characteristics of biodiesel from various non-edible vegetable oils: A review. Energy Convers. Manage. 2014;80:202-228.

51. Chauhan BS, Kumar N, Jun YD, Lee KB. Performance and emission study of preheated Jatropha oil on medium capacity diesel engine. Energy 2010;35:2484-2492.

52. Chauhan BS, Kumar N, Cho HM. A study on the performance and emission of a diesel engine fuelled with Jatropha oil and its blends. Energy 2012;37:616-622.

53. Wan Ghazali WNM, Mamat R, Masjuki HH, Najafi G. Effects of biodiesel from different feedstock on engine performance and emissions: a review. Renew. Sust. Energ. Rev. 2015;51: 585-602.

54. Ali Y, Hanna MA, Cuppett SL. Fuel properties of tallow and soybean oil esters. J. Am. Oil Chem. Soc. 1995;72:1557-1564.

55. Szybist JP, Song J, Alam M, Boehman AL. Biodiesel combustion, emission and emission control. Fuel Process. Technol. 2007;88:679-691.
56. Mofijur M, Masjuki HH, Kalam MA, Atabani AE. Evaluation of biodiesel blending, engine performance and emissions characteristics of Jatropha curcas methyl ester: Malaysian perspective. Energy 2013; 55:879-887.

57. Rao PV. Experimental investigations on the Influence of Properties of Jatropha biodiesel on performance, combustion and emission characteristics of a DI-CI Engine. World Acad. Sci. Eng. Technol. 2011;5:855-868.

58. Alptekin E, Canakei M. Characterization of the key fuel properties of methyl ester-diesel fuel blends. Fuel 2009;88:75-80.

59. Ramfrez-Verduzco LF, Gareia-Flores BE, Rodriguez-Rodriguez JE, Del Rayo Jaramillo-Jacob A. Prediction of the density and viscosity in biodiesel blends at various temperature. Fuel 2011;90:1751-1761.

60. Kuti OA, Zhu J, Nishida K, Wang X, Huang Z. Characterization of spray and combustion processes of biodiesel fuel injected by diesel engine common rail system. Fuel 2013;104:838-846.

61. Tesfa B, Mishra R, Gu F, Powles N. Prediction models for density and viscosity of biodiesel and their effects on fuel supply system in CI engines. Renew. Energ. 2010;36:2752-2760.

62. Ryan TY, Knothe G. Cetane numbers of branched and straight-chain fatty esters determined ignition quality tester. Fuel 2003;82:971-975.

63. Rizwanul Fattah IM, Masjuki HH, Kalam MA. Experimental investigation of performance and regulated emissions of a diesel engine with Calophyllum inophyllum biodiesel blends accompanied by oxidation inhibitors. Energy Convers. Manage. 2014;83:232-240.

64. Rizwanul Fattah IM, Liaquat AM, Masjuki HH. Impact of various biodiesel fuels obtained from edible and non-edible oils on engine exhaust gas and noise emissions. Renew. Sust. Energ. Rev. 2013;18:552-567.

65. Sievers DL. Ignition delay characteristics of alternative diesel fuels implication on cetane number. SAE Transactions. 1985;94:673-686.

66. Harrington KL. Chemical and physical properties of vegetable oil esters and their effect on diesel fuel performance. Biomass 1986;9:1-17.

67. Knoth G. Cetane numbers-heat of combustion-Why vegetable oils and their derivatives are suitable as a diesel fuel. The Biodiesel Handbook. Champaign, IL: AOCS Press. 2005;1:4-16.

68. Motijur M, Rasul MG. Comparative evaluation of edible and non-edible oil methyl esters performance in a vehicular engine. Energy procedia. 2015;75:37-43.

69. Motijur M, Masjuki HH, Kalam MA. Comparative evaluation of performance and emission characteristics of Moringa oleifera and palm oil based biodiesel in a diesel engine. Ind. Crops Prod. 2014;53:78-84.

70. Pinto AC, Guarieiro LL, Rezende MJ, Ribeiro NM, Torres EA, Lopes WA. Biodiesel: an overview. J. Braz. Chem. Soc.2005;16: 1313-1330.

71. Tan ES, Kumaran P, Indra TMI, Tokimatsu K, Yoshikawa K. Impact of biodiesel application on fuel savings and emission reduction for power generation in Malaysia. Energy Procedia. 2019;158:3325-3330.

72. Masjjuki HH, kalam MA, Jayed MH. Prospects of dedicated biodiesel engine vehicles in Malaysia and Indonesia. Renew. Sust. Energ. Rev. 2011;15:220-235. 
73. Teong LK, Lin S. Recent trends, Opportunities and challenges of biodiesel in Malaysia: an overview. Renew. Sust. Energ. Rev. 2010;14:938-953.

74. Atadashi IM, Aroua MK, Abdul Aziz AR, Sulaiman MNM. Production of biodiesel using high free fatty acid feedstocks. Renew. Sust. Energ. Rev. 2012;16:3275-3286.

75. Atadashi IM, Aroua MK, Abdul Aziz A. High quality biodiesel and its diesel engine application; a review. Renew. Sust. Energ. Rev. 2010;14:1999-2008.

76. Sharma MP, Dwivedi G. Prospects of biodiesel from pongamia in India. Renew. Sust. Energ. Rev. 2014;32:114-122.

77. Sharma MP, Jain S. Prospects of biodiesel from Jatropha in India. Renew. Sust. Energ. Rev. 2010;14:763-771.

78. Das LM, Agarwal AK. Biodiesel development and characterization for use as a fuel in compression ignition engines. $J$ Eng Gas Turbine Power. 2001;123:440-447.

79. De Siqueira Cavalcantia EH, Zimmer AR, Bento FM, Ferrão MF. Chemical and microbial storage stability studies and shelf life determinations of commercial Brazilian biodiesels stored in carbon steel containers in subtropical conditions. Fuel 2019;236:993-1007.

80. Worgetter M, Prankl H. Influence of the iodine number of biodiesel to the engine performance. In: Third Liquid Fuel Conference Liquid fuels and Industrial Products from Renewable Resources; 15-l7 September 1996; Nashville, Tennessee;1996. p. 1-6.

81. Sahayaraj JW, Sundar Raj FRM. A Comparative study over alternative fuel (biodiesel) for environmental friendly emission. In: Recent Advances in Space Technology Services and Climate Change 2010 (RSTS \& CC-2010); 13-15 Nov. 2010; Chenna; 2010. p. 80-86.

82. Jain S, Sharma M. Stability of biodiesel and its blends: a review: Renew. Sust. Energ. Rev. 2010;14:667-678.

83. Atabani AE, Silitonga AS, Badruddin IA. A comprehensive review on biodiesel as an alternative energy resource and its characteristics. Renew. Sust. Energ. Rev. 2012;16:2070-2093.

84. Mukhaerjee S, Karmakar S. Properties of various plants and animals feedstock for biodiesel production. Bioresour. Technol. 2010;101:7201-7210.

85. Anwar F, Knothe G, Rashid U. Evaluation of biodiesel obtained from cottonseed oil. Fuel Process. Technol. 2009;90:1157-1163.

86. Dumn RO, Knothe G. Dependence of oil stability index of fatty compounds on their structure and concentration and presence of metals. J. Am. Oil Chem. Soc. 2003;80:1021-1026.

87. Balamurugan T. Experimental investigation on performance, combustion and emission characteristics of four stroke diesel engine using diesel blended with alcohol as fuel. Energy 2014;1-8.

88. Raman AL, Deepanraj B, Rajakumar S, Sivasubramanian V. Experimental investigation on performance, combustion and emission analysis of a direct injection diesel engine fuelled with rapeseed oil biodiesel. Fuel 2019;246:69-74.

89. John Panneer Selvam D, Vadivel K. Performance and emission analysis of DI diesel engine fuelled with methyl esters of beef tallow and diesel blends. Procedia Eng. 2012;38:342-358.

90. Rajaraman S, Yashwanth GK, Rajan T. Experimental investigation of performance and emission characteristics of moringa oil methyl ester and its diesel blends in a single cylinder direct injection diesel engine. In: ASME 2009 international mechanical engineering congress \& exposition; 13-19 Nov. 2009; lake Buena vista, florida; 2009. p. 27-34.

91. Bari S, Hossain SN. Performance and emission analysis of a diesel engine running on palm oil diesel (POD). Energy Procedia. 2019;160:92-99.

92. Vijayakumar M, Mukesh kumar PC. Diesel engine with biodiesel, N-propanol and 1-butanol blend. J. Appl. Fluid Mech. 2017;10: 79-84.

93. Arumugam K, Sathiyamoorthy V, Anbazhagan R, Suresh R. Performance and emission characteristics of CI engine fueled with 100\% palm biodiesel. Int. J. Pure Appl. Math. 2017;115: 265-273.

94. Iqbal AM, Zainal ZA, Mazlan M, Mustala Al Bakari, salim MS. Performance and Emission Characteristics of Diesel Engine Running on Blended Palm Oil. Adv. Mater. Res. 2013;795: 164-169.

95. Pramanik K. Properties and use of jatropha cruces oil and diesel fuel blends in compression ignition engine. Renew. Energ. 2003;28:239-248.

96. Asokan MA, Senthur Prabu S, Bade PKK, Nekkanti VM, Gutta SSG. Performance, Combustion and emission characteristics of juliflora biodiesel fuelled DI diesel engine. Energy 2019;173:883-892.

97. Srithar K, Arun Balasubramanian K, Pavendan V, Ashok kumar B. Experimental investigations on mixing of two biodiesel blended with diesel as alternative fuel for diesel engines. J. King Saud Univ. 2017;29:50-56.

98. Jafari M, Verma P, Bodisco TA, et al. Multivariate analysis of performance and emission parameters in a diesel engine using biodiesel and oxygenated additive. Energy Convers. Manage. 2019;201:112183.

99. Allen Jeffrey J. Effectiveness of palm oil biodiesel on performance and emission characteristics in a compression Ignition engine. Int. J. Sci. Eng. Technol. Res. 2017;6:546-550.

100. Usta N, Ozturk E, Can O, et al. Combustion of biodiesel fuel produced from hazelnut soapstock/waste sunflower oil mixture in a diesel engine. Energy Convers. Manage. 2005;46: 741-755.

101. Kalam MA, Masjuki HH, Varman M, Jayed MH, Liaquat AM. Emission and performance characteristics of an indirect ignition diesel engine fuelled with waste cooking oil. Energy 2011;36:397-402.

102. Goga G, Chauhan BS, Mahla SK, Cho H. Performance and emission characteristics of diesel engine fueled with rice bran biodiesel and n-butanal. Energy Reports. 2019;5:78-83.

103. Celebi Y, Aydin H. Investigation of the effects of butanol addition on safflower biodiesel usage as fuel in a generator diesel engine. Fuel 2018;222:385-393.

104. Motamedifar N, Shirneshan A. An experimental study of emission characteristics from cylindrical furnace: effects of using diesel-ethanol-biodiesel blends and air swirl. Fuel 2018;221: 233-239.

105. Zheng Z, Xia M, Liu H, Shang R, Ma G, Yao M. Experimental study on combustion and emissions of n-butanol/biodiesel under both blended fuel mode and dual fuel RCCI mode. 
Fuel. 2018;226:240-251.

106. Alptekin E, Canakci M, Ozsezen AN, Turkcan A, Sanli H. Using waste animal fat based biodiesel-bioethanol diesel fuel blends in a DI diesel engine. Fuel 2015;157:245-254.

107. De Oliveira A, De Morais AM, Valente OS, Sodre JR. Combustion characteristics, Performance and emission from a diesel power generator fuelled by B7-Ethanol Blends. Fuel Process. Technol. 2015;139:67-72.

108. Leite D, Santos RF, Bassegio D et al. Emissions and performance of a diesel engine affected by soybean, linseed, and crambe biodiesel. Ind. Crops Prod. 2019;130:267-272.

109. Kandasamy SK, Selvaraj AS, Rajagopal TKR. Experimental investigations of ethanol blended biodiesel fuel on automotive diesel engine performance, emission and durability characteristics. Renew. energy. 2019;1481:1-27.

110. Zare A, Timothy A. Bodisco, Puneet Verma, et al. Emissions and performance with diesel and waste lubricating oil: A fundamental study into cold start operation with a special focus on particle number size distribution. Energy Convers. Manage. 2020;209:112604.

111. Verma P, Jafari M, Ashrafur Rahman SM, et al. The impact of chemical composition of oxygenated fuels on morphology and nanostructure of soot particles. Fuel 2020;259:116167.

112. Verma P, Jafari M, Guo Y, et al. Experimental Analysis of the Morphology and Nanostructure of Soot Particles for Butanol/Diesel Blends at Different Engine Operating Modes. Energy fuels. 2019;33:5632-5646.

113. Verma P, Pickering E, Jafari M, et al. Influence of fuel oxygen content on morphology and nanostructure of soot particles. Combust. Flame. 2019;205:206-219.

114. Chhabra M, Sharma A, Dwivedi G. Performance evaluation of diesel engine using rice bran biodiesel. Egypt. J. Pet. 2017;26:511-518.

115. Rosha P, Mohapatra SK, Mahla SK, Cho HM, Chauhan BS, Dhir A. Effect of compression ratio on combustion, performance and emission characteristics of compression ignition engine fuelled with palm (B20) biodiesel blend. Energy 2019;178:676-684.
116. Kumar P, Sharma MP, Dwivedi G. Impact of ternary blends of biodiesel on diesel engine performance. Egypt. J. Pet. 2016;25:255-261.

117. Vijayakumar M, Mukesh kumar PC. Performance Enhancement and Emissions Analysis of Diesel Engine with Biodiesel, N-Propanol and 1-Butanol Blend. J. Appl. Fluid Mech. 2017;10:79-84.

118. Yasin MHM, Paruka P, Mamat R, Yusop AF, Najafi G, Alias A. Effect of Low Proportion Palm Biodiesel Blend on Performance, Combustion and Emission Characteristics of a Diesel Engine. Energy Procedia. 2015;75:92-98.

119. Kumar K, Sharma MP. Performance and Emission Characteristics of a Diesel Engine Fuelled with Biodiesel Blends. Int. J. Renew. Energy Res. 2016;6:658-662.

120. Arumugam K, Sathiyamoorthy V, Anbazhagan R, Suresh R. Performance and emission characteristics of $\mathrm{CI}$ engine fuelled with $100 \%$ palm biodiesel: an experimental study. Int. J. Pure Appl. Math. 2017;8:265-273.

121. Samsukumar R, Muaralidhararao M, Gopala Krishna A, et al. Performance and Emission Analysis on CI Engine with Palm Oil Biodiesel Blends at Different Fuel Injection Pressures. Int. J. Innov. Res. Sci. Eng. Technol. 2015;4:2347-6710.

122. Krishna SM, Abdul Salam P, Tongroon M, Chollacoop N. Performance and emission assessment of optimally blended biodiesel-diesel-ethanol in diesel engine generator. Appl. Therm. Eng. 2019;18:1359-4311.

123. Qi DH, Chen H. Experimental studies on the combustion characteristics and performance of a direct injection engine fueled with biodiesel-diesel blends. Energy Convers. Manage. 2010;51:2985-2992.

124. Adu-Jrai A, Yamin JA, Al Muhtaseb AH, Hararah MA. Combustion characteristics and engine emission of a diesel engine fueled with diesel and treated waste cooking oil blends. Chem. Eng. J. 2011;172:129-136.

125. Lakshmi Narayana Rao G, Durga Prasad B. Combustion analysis of diesel engine fuelled with jatropha methyl ester biodiesel-diesel blends. Int. J. Green Energy. 2007;4:45-58. 